\title{
Deteksi Defect Coffee Pada Citra Tunggal Green Beans Menggunakan Metode Ensamble Decision Tree
}

Detection of Defect Coffee in Green Beans Single Image Using the Ensemble Decision Tree Method

\author{
Ami Rahmawati ${ }^{1}$, Yan Rianto ${ }^{2}$, Dwiza Riana ${ }^{3}$ \\ ${ }^{1,2,3}$ Program Studi Ilmu Komputer, Sekolah Tinggi Manajemen Informatika dan Komputer Nusa \\ Mandiri \\ E-mail: 1ami.amv@nusamandiri.ac.id, ${ }^{2}$ y_rianto@yahoo.co.jp, ${ }^{3}$ dwiza@ nusamandiri.ac.id
}

\begin{abstract}
Abstrak
Kopi merupakan salah satu komoditas minuman unggulan, sehingga permintaan biji kopi meningkat dari tahun ke tahun. Permintaan biji kopi didasarkan pada kualitas. Terdapat bebarapa faktor yang mempengaruhi kualitas antara lain bagaimana kopi ditanam dan dipanen, adapun kurangnya nutrisi dan perlindungan tanaman yang tidak memadai, maka akan menghasilkan kopi yang berkualitas rendah. Biji kopi berkualitas rendah sering kali disebut defects. Identifikasi defects coffee sangat penting khususnya bagi para petani dan pengusaha kopi agar dapat memilih biji kopi yang berkualitas tinggi sehingga meningkatkan nilai jual biji kopi. Pada beberapa industri kopi maupun makanan, teknik untuk mengidentifikasi cacat biji kopi biasa dengan cara seleksi manual dan mekanik, yang mana membutuhkan waktu yang lama dan dapat merusak biji kopi. Oleh karena itu diperlukan suatu pendekatan yang lebih modern dalam mengidentifikasi cacat biji kopi seperti pengolahan citra. Untuk itu penelitian ini bertujuan melakukan pengolahan citra berupa segmentasi pada citra green beans coffee menggunakan metode thresholding. Setelah itu dilakukan analisis tekstur menggunakan GLCM (Grey Level Co-occurence Matrix) dan dilanjutkan dengan pemodelan klasifikasi menggunakan algoritma C4.5 dengan bagging. Dari hasil penelitian yang diperoleh, akurasi dari penggunaan algoritma C4.5 dengan bagging sebesar 94\%.
\end{abstract}

Kata kunci: Defect Coffee, Thresholding, Algoritma C4.5.

\begin{abstract}
Coffee is one of the leading beverage commodities, so the demand for coffee beans increases from year to year. Demand for coffee beans is based on quality. There are several factors that affect quality, including how coffee is grown and harvested, as for the lack of nutrition and inadequate plant protection, it will produce low quality coffee. Low quality coffee beans are often called defects. The identification of coffee defects is very important especially for farmers and coffee entrepreneurs to be able to choose high-quality coffee beans that increase the selling value of coffee beans. In some coffee and food industries, techniques for identifying defects of ordinary coffee beans by means of manual and mechanical selection, which takes a long time and can damage coffee beans. Therefore a more modern approach is needed in identifying coffee bean defects such as image processing. For this reason, this study aims at image processing in the form of segmentation of green beans coffee using the thresholding method. After that the texture analysis is done using GLCM (Gray Level Co-occurrence Matrix) and proceed with classification modeling using C4.5 algorithm with bagging. From the research results obtained, the accuracy of the use of the C4.5 algorithm with bagging is $94 \%$.
\end{abstract}

Keywords: Defect Coffee, Thresholding, C4.5 Algorithm. 


\section{PENDAHULUAN}

Kopi merupakan salah satu komoditas minuman unggulan yang diperdagangkan di pasar dunia maupun Indonesia, sehingga permintaan biji kopi meningkat dari tahun ke tahun [1]. Berdasarkan data dinas perkebunan pada tahun 2018 jumlah produksi kopi di Indonesia mencapai 722,461 ton dengan provinsi jawa barat sebagai salah satu dari sepuluh besar provinsi yang berkontribusi terhadap produksi kopi sebesar 19,602 ton [2].

Permintaan biji kopi didasarkan pada kualitas [3], yang merupakan aspek utama industri kopi untuk menghasilkan produk berkualitas tinggi yang dijadikan sebagai dasar kesuksesan pasar kompetitif saat ini [4]. Bebarapa faktor yang mempengaruhi kualitas antara lain bagaimana kopi ditanam dan dipanen, adapun kurangnya nutrisi dan perlindungan tanaman yang tidak memadai, maka akan menghasilkan kopi yang berkualitas rendah [5]. Karakteristik sensasi rasa kopi yang tidak menyenangkan akibat biji kopi berkualitas rendah sering kali disebut defects coffee atau cacat kopi yang mana cacat tersebut dapat diketahui berdasarkan fisik, rasa dan aroma pada biji kopi [6]. Dalam defects coffee terdapat 14 jenis cacat diantaranya insect damage, black, sour, faded, dan broken [7]. Pada penelitian ini ada dua jenis defects coffe yang akan diidentifikasi yaitu black dan insect damage. Kedua jenis defects coffee tersebut dipilih karena memiliki total cacat lebih dari $4 \%$ sehingga tidak dapat ditoleransi kecacatannya [8].

Identifikasi defects coffee sangat penting khususnya bagi para petani dan pengusaha kopi agar dapat memilih biji kopi yang berkualitas tinggi sehingga meningkatkan nilai jual biji kopi [9]. Pada beberapa industri kopi maupun makanan, Teknik untuk mengidentifikasi cacat biji kopi biasa dengan cara seleksi manual dan mekanik. Teknik seleksi manual dilakukan oleh seorang ahli dengan menginspeksi visual terhadap biji kopi dan mengidentifikasi fitur spesifik dari biji kopi untuk memilih yang terbaik, namun pemilihan tidak seragam dikarenakan membutuhkan jam kerja yang lama [10]. Teknik mekanik dilakukan dengan mesin yakni mensortir biji kopi berdasarkan ukurannya, namun didalam teknik ini dapat berpotensi merusak biji kopi [11]. Oleh karena itu tidak ada teknik yang memberikan pilihan terbaik untuk memilih biji kopi berkualitas, yang berarti diperlukan suatu pendekatan yang lebih modern seperti pengolahan citra.

Ada banyak peneliti yang sudah melakukan penelitian untuk mengidentifikasi defect coffee, seperti penelitian yang dilakukan oleh [1] tentang algoritma KNN yang digunakan untuk menentukan kualitas biji kopi dan jenis cacat yang sesuai. Sistem ini terdiri dari logical proses, image processing dan algoritma supervised learning dengan menggunakan MATLAB. Penelitian selanjutnya dilakukan oleh [12] tentang identifikasi kualitas biji kopi menggunakan teknik image processing melalui ekstraksi komponen warna RGB dari sebuah citra. Penelitian selanjutnya dilakukan oleh [9] tentang perancangan aplikasi yang dapat mendeteksi kualitas biji kopi mentah baik dan buruk berdasarkan nilai HSI (Hue Saturation Intensity) pada biji kopi menggunakan pengolahan citra digital dan jaringan syaraf tiruan Backpropagation. Penelitian selanjutnya dilakukan oleh [7] tentang pemeriksaan catat biji dengan GAN-Structured Automated Labeled Data Augmentation di industry kopi menggunakan deep learning, Generative-Adversarial Network, Automated Labeled Data Augmentation. Penelitian selanjutnya dilakukan oleh [13] tentang Meningkatkan Kualitas Pemeriksaan Cacat Jaringan dengan Deep-Learning pada Kacang Padat dengan Menggunakan Hough Circle Transform untuk Industri Kopi. Penelitian selanjutnya dilakukan oleh [14] tentang Klasifikasi Citra Biji Kopi Hijau Berdasarkan Jenis Cacat Menggunakan Convolutional Neural Network (CNN).

Merujuk pada hasil penelitian-penelitian tersebut, maka pada penelitian ini akan mendeteksi defect coffee pada citra tunggal yang didapatkan dari bumi kopi goalpara sukabumi dengan menggunakan machine learning. Machine learning pada saat ini menjadi jalan yang optimal dengan tujuan untuk mendapatkan algoritma terlatih yang dapat mengidentifikasi cacat biji kopi [15]. Untuk dapat mengidentifikasi cacat biji kopi tersebut diperlukan kualitas citra yang baik. Oleh karena itu pada penelitian ini akan dilakukan tahapan preprocessing meliputi noise remover, shadow remover, dan segmentasi yang bertujuan untuk menghasilkan kualitas citra yang diharapkan. Selain itu, teknik machine learning yang akan digunakan yaitu klasifikasi 
Algoritma Decision Tree (C4.5) dengan Bagging yang nantinya akan menunjukkan keakuratan dari hasil prediksi cacat biji kopi.

\section{METODE PENELITIAN}

2.1 Tahapan Penelitian

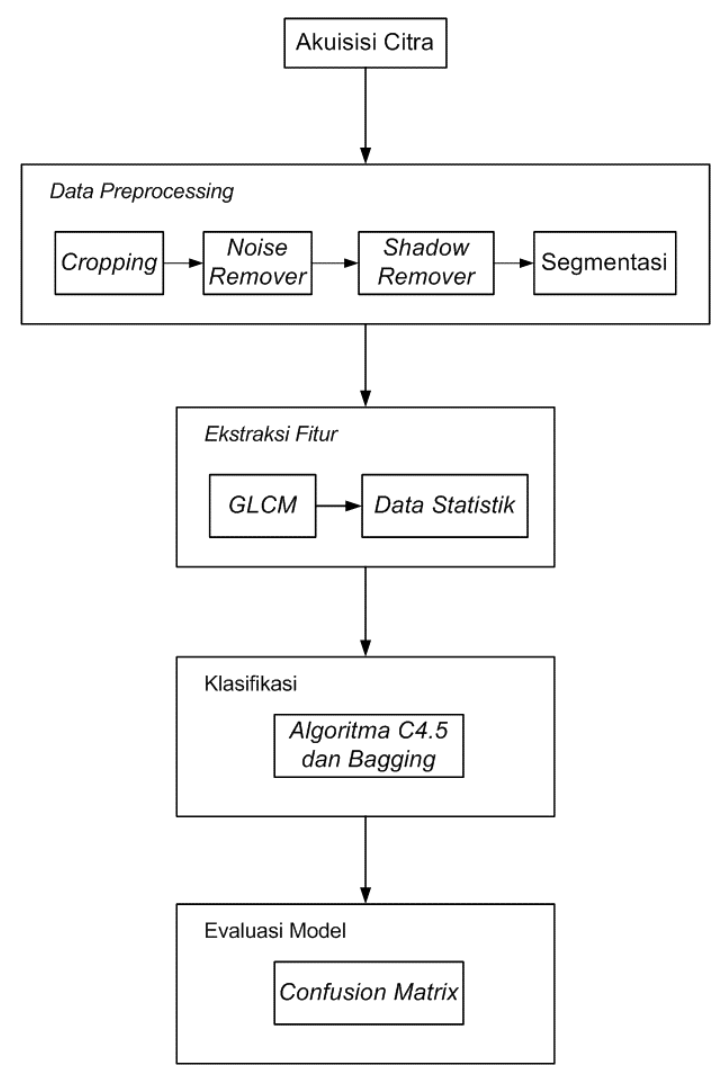

Gambar 1. Model Tahapan Penelitian

Pada tahapan penelitian diatas menjelaskan bahwa untuk mendeteksi defect coffee pada citra green beans dimulai dari akuisisi citra kemudian dilakukan data preprocessing meliputi cropping, noise remover menggunakan Gaussian, shadow remover menggunakan Absolute Difference dan segmentasi menggunakan metode Thresholding terhadap citra tersebut. Selanjutnya citra yang sudah tersegmentasi diekstraksi menggunakan GLCM (Gray Level Cooccurrence Matrix) untuk mendapatkan fitur dan data statistik. Setelah itu data akan diuji dengan metode data mining klasifikasi algoritma $\mathrm{C} 4.5$ dan teknik Bagging yang akan divalidasi dengan menggunakan confusion matrix untuk mengetahui nilai akurasi.

\subsection{Gaussian}

Filter gaussian adalah alat perataan yang efisien dalam visi komputer. Berdasarkan pada kernel gaussian, Witkin [Witkin (1983)] dan Koenderink secara resmi mendefinisikan konsep ruang-skala pada tahun 1983 - 1984, menyatukan serangkaian gambar turunan yang tidak terkait pada berbagai tingkat detail sepanjang parameter skala dan memungkinkan data gambar untuk menjadi diintegrasikan ke dalam perspektif yang berkelanjutan. Sejak itu, kernel Gaussian telah sering dipelajari dalam hubungannya dengan apa yang disebut "multiple scale approach". Namun scale-space filtering telah diterapkan dalam gambar 2D [Kuijiper dan Florack (2001)] [Bauer dan Peikert (2002)] [Lindberg (1995)] [Linberg (1998)], dan baru-baru ini saja teknik ini digunakan dalam grafik komputer, dengan aplikasi terbatas dalam visualisasi 3D. Filter intrinsik, generalisasi scale-space filtering, digunakan untuk menghilangkan noise dari gambar dan data yang dipindai [Boulanger et al. (2002)]. Peneliti yang relatif lebih sedikit telah melihat 
ke penyederhanaan model 3D (atau mesh) berdasarkan analisis titik fitur pada berbagai skala [16]. gaussian [17]

Dalam satu dimensi kernel Go $(x)$ dari filter gaussian domain diberikan oleh fungsi

$\mathrm{G} \sigma(x)=\frac{1}{\sigma \sqrt{2 \pi}} e^{-x^{2} /\left(2 \sigma^{2}\right)}$

Di mana $\sigma$ adalah sebuah konstanta, yang disebut variance function dalam dua dimensi, kernel didefinisikan oleh [17]

$\mathrm{G} \sigma(x, \mathcal{Y})=\frac{1}{2 \sigma^{2} \pi} e^{-\left(x^{2}+y^{2}\right) /\left(2 \sigma^{2}\right)}$

Analisis cepat dalam domain kontinu menunjukkan bahwa filter gaussian adalah filter lowpass. Transformasi fourier dari distribusi gaussian juga merupakan gaussian. fungsi transfer bersifat gaussian, sehingga frekuensi tinggi dalam sinyal yang disaring diredam oleh faktor yang tumbuh secara eksponensial dengan frekuensi [17].

\subsection{Absolute Difference}

Ukuran perbedaan antara gambar berfungsi sebagai fitur untuk mengukur kesamaan, terdapat dua metode dasar untuk perbedaan gambar: perbedaan absoulte dan perbedaan histogram. Absolute difference membutuhkan lebih sedikit perhitungan, tetapi umumnya lebih rentan terhadap noise dan artifak pencitraan lainnya. Perbedaan gambar dari dua gambar didefinisikan sebagai jumlah dari perbedaan absolute pada setiap piksel. Gambar pertama dianalisis dengan gambar kedua, $\mathrm{I}_{\mathrm{t}=\mathrm{T}}$, pada jarak temporal $\mathrm{T}$. Nilai difference didefinisikan sebagai berikut [18] :

$D\left(t=\sum_{i=1}^{M}\left|I_{t-T}(\mathrm{i})-I_{t}(\mathrm{i})\right|\right)$

Dimana $\mathrm{M}$ adalah resolusi, atau jumlah piksel dalam gambar. Metode ini untuk perbedaan gambar noise dan sangat sensitif terhadap gerakan kamera dan degradasi gambar [18].

\subsection{GLCM (Gray Level Co-occurrence Matrix)}

GLCM atau matriks dependensi spasial gray-tone. Konsep utama GLCM adalah bahwa informasi tekstur yang terkandung dalam gambar ditentukan oleh hubungan kedekatan yang harus dimiliki gray-tone dalam gambar. Dengan kata lain, diasumsikan bahwa informasi tekstur ditentukan oleh nilai $f_{i j}$ dalam GLCM, di mana $f_{i j}$ menunjukkan frekuensi kemunculan dua sel tone abu-abu i dan $\mathrm{j}$, masing-masing, dipisahkan oleh jarak d dengan arah khusus pada gambar. Nilai $f_{i j}$ dapat dihitung untuk setiap arah dan jarak yang layak d. Umumnya, hanya empat arah yang sesuai dengan sudut $0^{\circ}, 45^{\circ}, 90^{\circ}, 135^{\circ}$ yang digunakan [19].

\subsection{Algoritma C4.5}

Algoritma ini diperkenalkan oleh Quinlan (1996) untuk mengatasi kelemahan dari ID3 yang tidak dapat menangani atribut bertipe numerik. Pada prinsipnya, cara kerja algoritma C4.5 sama dengan ID3, yaitu menggunakan nilai Gain dalam menentukan fitur/atribut yang menjadi pemecah node pada pohon keputusan. Perbedaannya adalah algoritma $\mathrm{C} 4.5$ dapat menangani atribut bertipe numerik dengan cara melakukan diskretisasi data terhadap atribut bertipe numerik. Pendekatan untuk menyatakan syarat pengujian pada node terdiri atas [20] :

1. Pemecahan pada Atribut Binomial/Biner

2. Pemecahan pada Atribut Nominal (Kategorikal)

3. Pemecahan pada Atribut Numerik

Proses pembentukan pohon keputusan dengan algoritma C4.5 yaitu [21] : 
1. Entropy $(S)$ adalah parameter yang digunakan untuk mengukur keberagaman setiap nilai attribute kriteria terhadap decision attribute (atribut keputusan) dalam sebuah kumpulan data. Makin rendah nilai Entropy maka tingkat keberagaman suatu kumpulan data makin rendah, sebaliknya makin tinggi nilai Entropy maka nilai keberagaman makin tinggi. Rumus Entropy sebagai berikut:

$\operatorname{Entropy}(S)=\sum_{i=n}^{n}-p i * \log _{2}(p i)$

Keterangan :

$\mathrm{S}=$ Jumlah sampel data (Sampling)

$\mathrm{n} \quad=$ Jumlah partisi $\mathrm{S}$

pi $=$ Proporsi dari $S_{\mathrm{i}}$ terhadap $\mathrm{S}$

2. Gain $(S, A)$ adalah selisih nilai Entropy total dikurangi nilai Entropy masing-masing nilai setiap attribute kriteria dikali nilai proporsi nilai attribute dibagi jumlah sampel data. Fungsi dari nilai Gain adalah untuk mengukur efektivitas masing-masing attribute kriteria dalam mengklasifikasikan data. Pada algoritma C4.5 nilai Gain digunakan sebagai dasar pembentukan node atau akar dan cabang pohon keputusan. Rumus Gain adalah sebagai berikut:

$\operatorname{Gain}(S, A)=\operatorname{Entropy}(S)-\sum_{i=1}^{n} \frac{|S i|}{|S|} * \operatorname{Entropy}(S i)$

Keterangan :

$\mathrm{S}=$ Jumlah kasus (Sampling)

$\mathrm{A}=$ Attribute

$\mathrm{n} \quad=$ Jumlah partisi $\mathrm{S}$

$|\mathrm{Si}|=$ Jumlah kasus pada partisi ke- $i$

$|\mathrm{S}|=$ Jumlah kasus dalam $\mathrm{S}$

\section{HASIL DAN PEMBAHASAN}

Penelitian ini bertujuan untuk memperoleh hasil akurasi terbaik dengan menggunakan model algoritma C4.5 dan bagging dalam mendeteksi defect coffee berdasarkan kumpulankumpulan image yang telah di ekstraksi.

\section{a. Dataset}

Data yang digunakan pada penelitian ini menggunakan data primer. Data penelitian diambil dengan cara memotret defect pada green beans coffee yang diperoleh dari Bumi Kopi Goalpara Sukabumi, dengan jumlah 400 image yang terdiri dari 150 image untuk black coffee, 150 image untuk damage coffee, dan 100 image untuk normal (non-defect coffee).

\section{b. Akuisisi Citra}

Pengambilan gambar defect coffee dilakukan menggunakan kamera smartphone Samsung galaxy A6 dengan resolusi 16 MP dengan piksel 4608 x 3456. Gambar defect coffee diambil secara tunggal dan ditempatkan pada latar belakang putih. Kamera diatur pada zoom 4,0x ditahan dalam posisi normal pada bidang biji defect coffee dengan jarak 5,1 inchi tepat diatas bidang sampel. Gambar tersebut disimpan dalam format JPG. Citra defect coffee tersebut diambil dari bumi kopi goalpara sukabumi yang ditunjukkan pada gambar 2 berikut: 


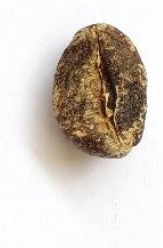

(a)

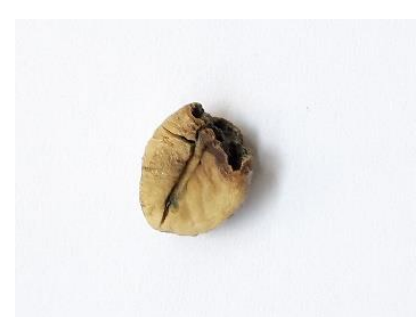

(b)

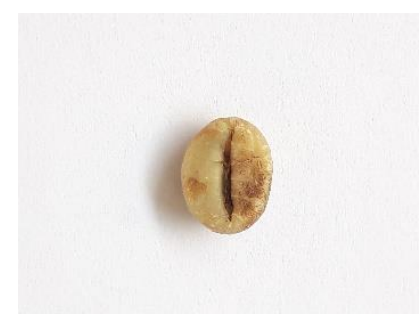

(c)

Gambar 2. Sampel Citra Defect Coffee

a. Black Coffee; b. Damaged Coffee; c. Non-Defect Coffee

\section{c. Cropping}

Pada tahap preprocessing dilakukan proses cropping pada citra dikarenakan gambar yang dihasilkan oleh kamera cukup besar. Ukuran piksel 4608 x 3456 dirubah menjadi 2500 x 2400. Perubahan ukuran tersebut ditunjukkan pada gambar 3 berikut:
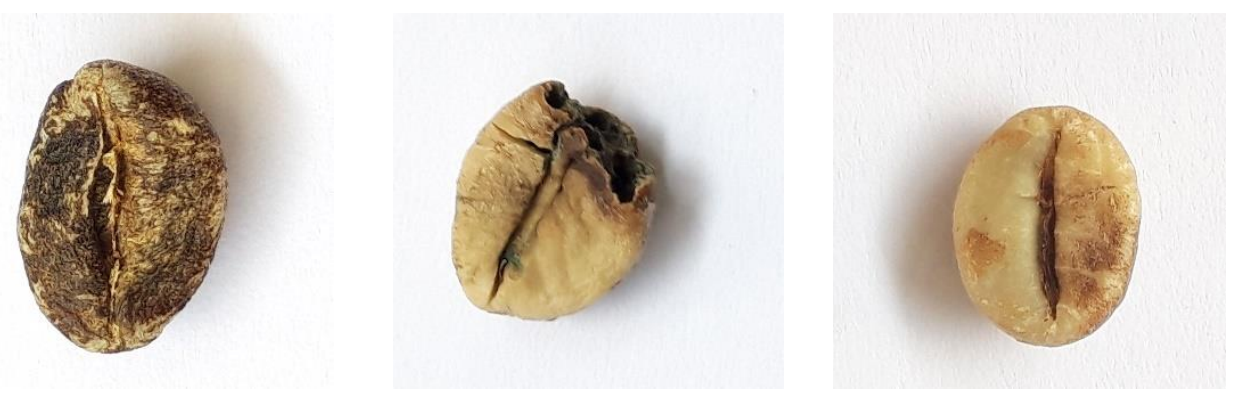

Gambar 3. Image Cropping

\section{d. Noise Remover}

Gambar-gambar yang telah diambil oleh kamera terdapat noise. Noise tersebut dapat menyebabkan pemrosesan gambar menjadi buruk. Untuk menghilangkan noise yang terdapat pada gambar dalam penelitian ini menggunakan Gaussian Blur dalam opencv. Gaussian Blur akan memindai setiap piksel gambar dan menghitung ulang nilai piksel berdasarkan nilai piksel yang mengelilinginya, area yang di pindai di sekitar setiap piksel disebut dengan kernel. Langkah-langkah menghilangkan noise dengan Gaussian Blur disajikan dalam flowchart (Gambar 4) sebagai berikut : 


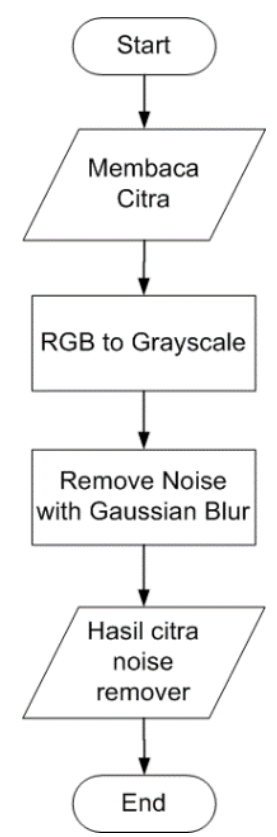

Gambar 4. Flowchart Noise Remover

Penjelasan untuk flowchart noise remover pada gambar 4.3 adalah :

1. Membaca citra.

2. Citra asal yang bertipe RGB dikonversi menjadi grayscale. Citra grayscale merupakan citra yang nilai intensitas pikselnya berdasarkan derajat keabuan. Konversi citra dilakukan untuk memudahkan proses pada metode Gaussian Blur.

3. Gaussian Blur memfilter gambar 2D yaitu citra grayscale dengan ukuran kernel 51 x 51 dan standard deviation adalah 0.

4. Menampilkan hasil citra.

e. Shadow Remover

Untuk menghilangkan bayangan pada gambar dalam penelitian ini menggunakan Absolute Difference dalam opencv. Absolute Difference digunakan untuk mengurangi informasi yang tidak perlu termasuk dapat menghilangkan bayangan dalam sebuah gambar dengan cara menemukan perbedaan absolut antara piksel dari dua array gambar. Langkah-langkah menghilangkan bayangan dengan Absolute Difference disajikan dalam flowchart (Gambar 5) sebagai berikut : 


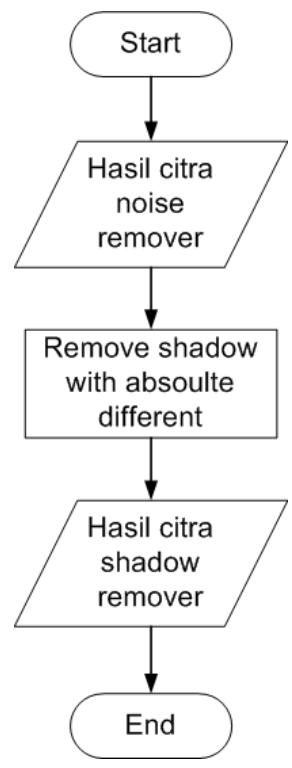

Gambar 5. Flowchart Shadow Remover

Penjelasan untuk flowchart shadow remover pada gambar 4.4 adalah :

1. Membaca citra dari hasil noise remover.

2. Absolute Difference digunakan dengan cara mengurangi nilai 255 dengan citra grayscale dan citra noise remover.

3. Menampilkan hasil citra.

\subsection{Segmentasi}

Segmentasi citra yang digunakan adalah teknik Thresholding. Segmentasi citra mengacu pada proses membagi gambar menjadi beberapa bagian untuk tujuan membedakan objek dengan background yang mana diperlukan untuk menjalankan ekstraksi fitur. Proses segmentasi pada penelitian ini menghapus background dan mengganti background tersebut menjadi hitam akan tetapi untuk warna objek tetap yaitu RGB, maka digunakan metode deteksi warna. Setelah semua ruang warna di coba maka HSV (Hue, Saturation, dan Value) dan grayscale menjadi pilihan terbaik untuk proses segmentasi defect coffee beans. Hasil proses segmentasi ditunjukkan pada gambar 6 berikut :

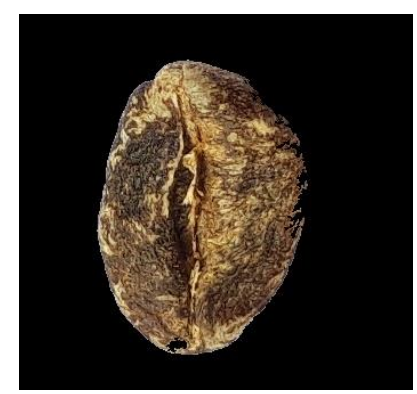

3.7 Ekstraksi Fitur

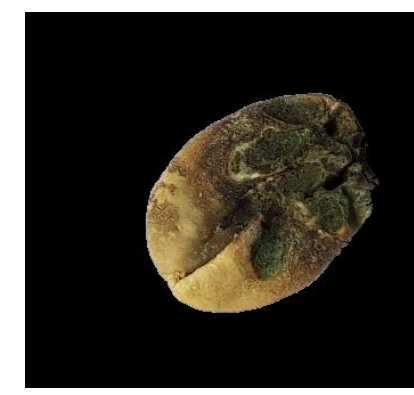

Gambar 6. Hasil Segmentasi

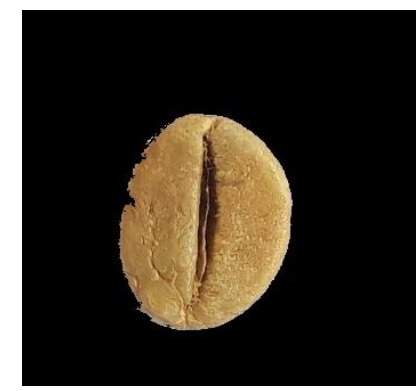

Untuk ekstraksi fitur yang digunakan adalah GLCM (Gray Level Co-occurrence Matrix). GLCM akan menghasilkan matriks baru dengan cara menghitung nilai kemungkinan pada piksel tetangganya. Matriks yang terbentuk berjumlah 4 dengan sudut 0, 45, 90, dan 135 derajat, akan tetapi yang digunakan pada penelitian ini sudut $0^{\circ}$. Proses ekstraksi tersebut menghasilkan 6 (enam) fitur yaitu Contrast, Correlation, Homogeneity, ASM, Disimilarity, Energy. Setelah fitur diketahui maka selanjutnya menghitung rata-rata data statistik. Hasil 
perhitungan tersebut disimpan dalam format CSV dan akan menjadi data input untuk data latih dan data uji yang ditunjukkan pada tabel 1 berikut :

Tabel 1. Hasil Ekstraksi Fitur

\begin{tabular}{|c|c|c|c|c|c|c|}
\hline Contrast & Correlation & Homogeneity & ASM & Disimilarity & Energy & Class \\
\hline 0.294891 & 0.974451 & 0.934721 & 0.520494 & 0.149324 & 0.72145 & $\begin{array}{c}\text { Black } \\
\text { Coffee }\end{array}$ \\
\hline 0.334647 & 0.973339 & 0.927062 & 0.486048 & 0.167601 & 0.697168 & $\begin{array}{c}\text { Black } \\
\text { Coffee }\end{array}$ \\
\hline 0.322861 & 0.9739 & 0.928864 & 0.487774 & 0.162938 & 0.698405 & $\begin{array}{c}\text { Black } \\
\text { Coffee }\end{array}$ \\
\hline 0.314337 & 0.972303 & 0.926171 & 0.502878 & 0.167707 & 0.709136 & $\begin{array}{c}\text { Black } \\
\text { Coffee }\end{array}$ \\
\hline 0.313828 & 0.971834 & 0.92691 & 0.481521 & 0.165699 & 0.693913 & $\begin{array}{c}\text { Black } \\
\text { Coffee }\end{array}$ \\
\hline 0.139104 & 0.992309 & 0.97422 & 0.638414 & 0.060322 & 0.799008 & $\begin{array}{c}\text { Damaged } \\
\text { Coffee }\end{array}$ \\
\hline 0.185369 & 0.987164 & 0.965894 & 0.569974 & 0.079472 & 0.754965 & $\begin{array}{c}\text { Damaged } \\
\text { Coffee }\end{array}$ \\
\hline 0.235411 & 0.968954 & 0.958226 & 0.628033 & 0.099769 & 0.792484 & $\begin{array}{c}\text { Damaged } \\
\text { Coffee }\end{array}$ \\
\hline 0.275008 & 0.966241 & 0.956264 & 0.619025 & 0.107167 & 0.78678 & $\begin{array}{c}\text { Damaged } \\
\text { Coffee }\end{array}$ \\
\hline 0.217068 & 0.975394 & 0.957868 & 0.604277 & 0.098135 & 0.777351 & $\begin{array}{c}\text { Damaged } \\
\text { Coffee }\end{array}$ \\
\hline 0.140321 & 0.993177 & 0.977415 & 0.63876 & 0.054647 & 0.799224 & $\begin{array}{l}\text { Normal } \\
\text { Coffee }\end{array}$ \\
\hline 0.137985 & 0.993353 & 0.977533 & 0.63835 & 0.054119 & 0.798968 & $\begin{array}{l}\text { Normal } \\
\text { Coffee }\end{array}$ \\
\hline 0.150022 & 0.992657 & 0.977172 & 0.637856 & 0.055891 & 0.798659 & $\begin{array}{l}\text { Normal } \\
\text { Coffee }\end{array}$ \\
\hline 0.212686 & 0.991013 & 0.967396 & 0.5094 & 0.078998 & 0.713721 & $\begin{array}{l}\text { Normal } \\
\text { Coffee }\end{array}$ \\
\hline 0.184119 & 0.990808 & 0.975243 & 0.583269 & 0.062008 & 0.76372 & $\begin{array}{l}\text { Normal } \\
\text { Coffee }\end{array}$ \\
\hline
\end{tabular}

3.8 Hasil pengujian Model C4.5 dengan Bagging

Hasil dari uji coba yang dilakukan yaitu untuk menghasilkan nilai accuracy (confusion matrix). Model confusion matrix akan membentuk matrix yang terdiri dari true positif atau tupel positif dan true negatif atau tupel negatif, kemudian masukan data testing yang sudah disiapkan ke dalam confusion matrix sehingga didapatkan hasil pada tabel 2 di bawah ini:

Tabel 2. Confusion Matrix Algoritma C4.5 dengan Bagging

\begin{tabular}{|l|c|c|c|}
\hline & Black & Damaged & Normal \\
\hline Black & 48 & 0 & 0 \\
\hline Damaged & 1 & 38 & 2 \\
\hline Normal & 0 & 3 & 28 \\
\hline
\end{tabular}

Berdasarkan Tabel 2 dari 400 tupel dibagi menjadi data latih dan data uji dengan perbandingan pembagian yaitu 70:30 maka data yang digunakan untuk prediksi uji sebanyak $30 \%$ dari jumlah data masing-masing class. Terdapat rincian jumlah True Positive (TP) Black 48, False Negative (FN) Black 1, False Positive (FP) Black 0, dan True Negative (TN) Black 71. True Positive (TP) Damaged 38, False Negative (FN) Damaged 3, False Positive (FP) Damaged 3, dan True Negative (TN) Damaged 76. True Positive (TP) Normal 28, False Negative (FN) Normal 2, False Positive (FP) Normal 3, dan True Negative (TN) Normal 87. Dari data tersebut maka dapat dihitung nilai accuracy, precision, recall, fl-score, dan support. Data hasil olahan dapat dilihat pada gambar 7 berikut : 


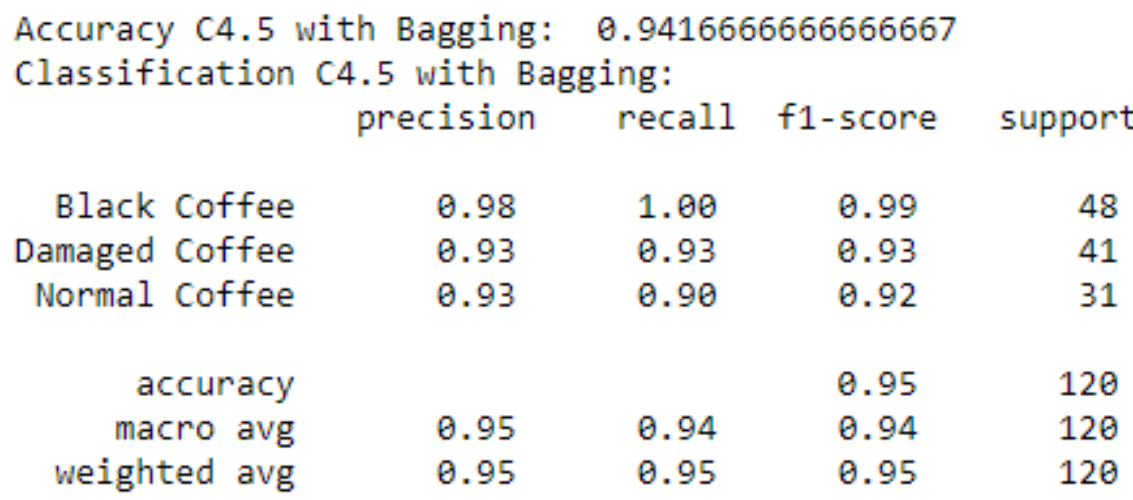

Gambar 7. Nilai Accuracy, Precision, Recall, F1-score, dan Support

Berdasarkan gambar 7 bahwa pengujian menggunakan algoritma C4.5 dengan bagging menghasilkan akurasi 94\% dan pohon keputusan yang terbentuk (lihat Gambar 8), dimana pohon keputusan tersebut terbentuk dengan memanfaatkan Framework Python 3.7.1.

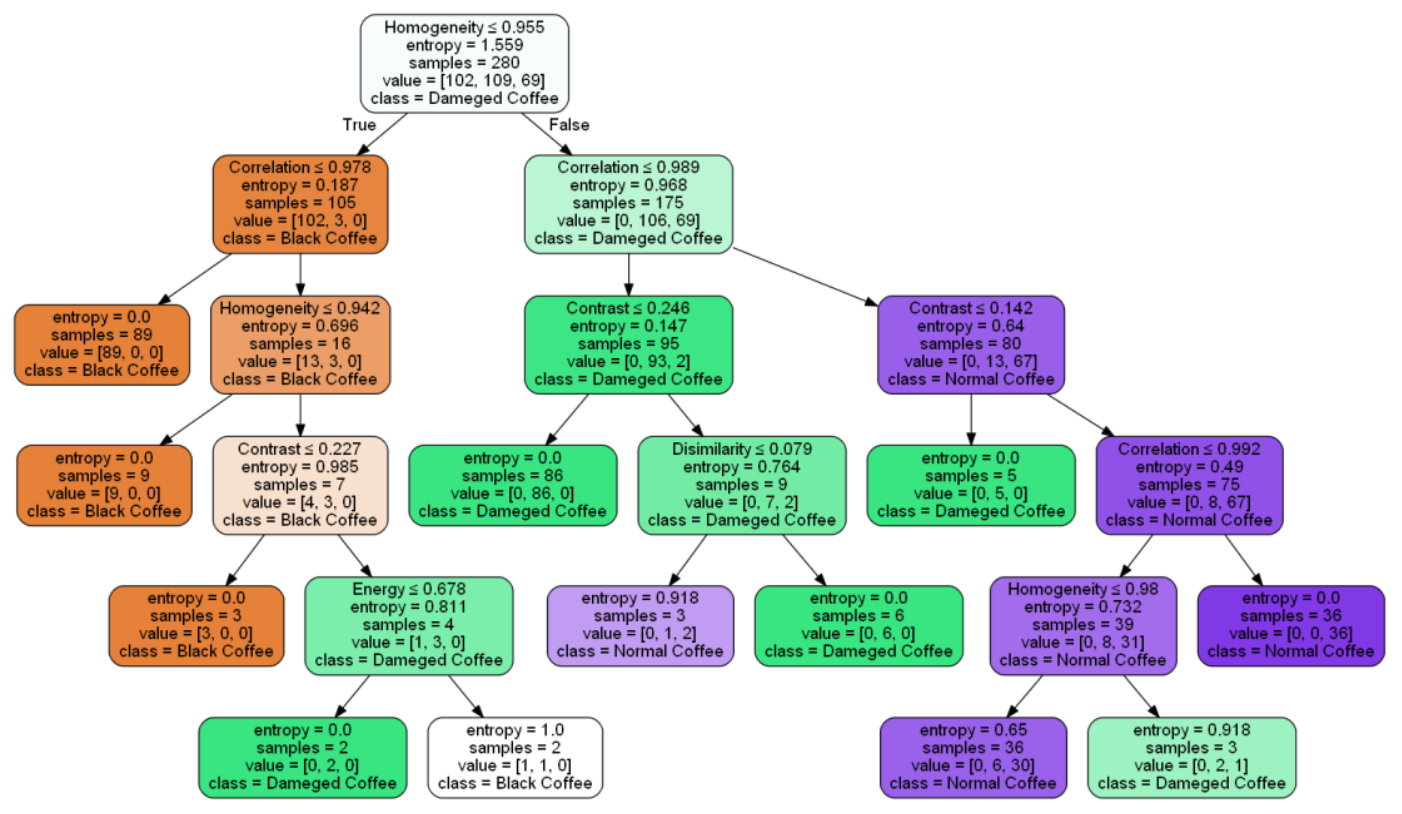

Gambar 8. Pohon Keputusan Klasifikasi Defect Coffee Beans

3.9 Pengembangan Aplikasi Model C4.5 dengan Bangging

Model yang dihasilkan dari eksperimen dikembangkan menjadi sebuah aplikasi. Aplikasi tersebut akan dikembangkan menggunakan bahasa pemrograman JAVA berbasis desktop yang akan dibuat dengan Netbeans 7.4. 


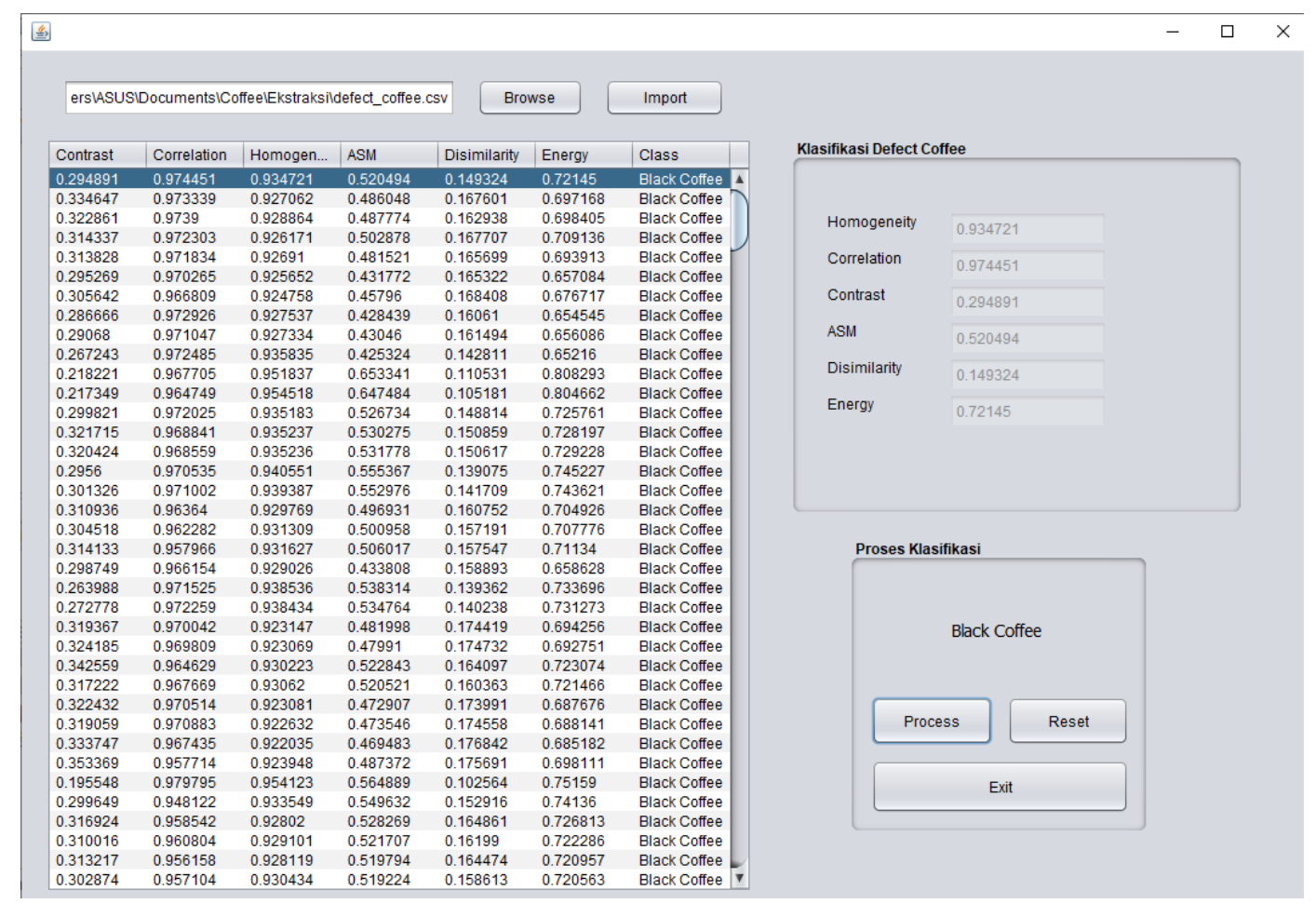

Gambar 9. Pengujian Aplikasi Model Algoritma C4.5 dengan Bagging

\section{KESIMPULAN DAN SARAN}

Dari hasil penelitian yang diperoleh, metode segmentasi yang cocok untuk mendeteksi defect coffee beans yaitu Thresholding dengan deteksi warna citra HSV (Hue, Saturation, dan Value) dan grayscale. Untuk ekstraksi fitur yang digunakan yaitu GLCM (Gray Level Cooccurrence Matrix). Akurasi dari penggunaan algoritma klasifikasi C4.5 dengan bagging dalam deteksi defect coffee beans sebesar 94\%. Berdasarkan penjelasan tersebut, penerapan metode Thresholding mampu mensegmentasi citra dengan baik, sehingga pada saat diuji menggunakan algoritma $\mathrm{C} 4.5$ dengan bagging menghasilkan tingkat akurasi yang baik.

\section{DAFTAR PUSTAKA}

[1] M. Garc and J. E. Candelo-becerra, "Quality and Defect Inspection of Green Coffee Beans Using a Computer Vision System," MDPI, vol. 9, pp. 2-18, 2019.

[2] Direktorat Jenderal Perkebunan, "Produksi Kopi Menurut Provinsi di Indonesia , 20152019 Coffee," vol. 2019, p. 2019, 2019.

[3] N. Caporaso, M. B. Whitworth, S. Grebby, and I. D. Fisk, "Rapid prediction of single green coffee bean moisture and lipid content by hyperspectral imaging," J. Food Eng., vol. 227, pp. 18-29, 2018.

[4] D. Fernandes, A. Lucia, D. S. Madureira, D. Sun, S. Lucy, and E. Yoko, "Application of infrared spectral techniques on quality and compositional attributes of coffee : An overview," FRIN, vol. 61, pp. 23-32, 2014.

[5] E. R. Arboleda, "An Image Processing Technique for Coffee Black Beans Identification," 2018 IEEE Int. Conf. Innov. Res. Dev., pp. 1-5, 2018.

[6] Coffeeland Indonesia, "MENGIDENTIFIKASI DEFECT PADA KOPI," Coffeeland, 2020. [Online]. Available: coffeeland.co.id/.

[7] Y. Chou et al., "Deep-Learning-Based Defective Bean Inspection with GAN-Structured Automated Labeled Data Augmentation in Coffee Industry," MDPI, vol. 9, pp. 2-26, 
2019.

[8] Dani, "Seputar Kopi," 2020.

[9] H. A. L. Nasution H T, Rumansa H, "Designing the quality of coffee bean detection application using Hue Saturation Intensity Designing the quality of coffee bean detection application using Hue Saturation Intensity," IOP Conf. Ser. Mater. Sci. Eng., no. 648, pp. 1-7, 2019.

[10] N. Razmjooy, B. S. Mousavi, and F. Soleymani, "A real-time mathematical computer method for potato inspection using machine vision," Comput. Math. with Appl., vol. 63, no. 1, pp. 268-279, 2012.

[11] M. Baigvand, A. Banakar, S. Minaei, J. Khodaei, and N. Behroozi-khazaei, "Machine vision system for grading of dried figs," Comput. Electron. Agric., vol. 119, pp. 158$165,2015$.

[12] E. R. Arboleda, A. C. Fajardo, and R. P. Medina, "Classification of Coffee Bean Species Using Image Processing, Artificial Neural Network and K Nearest Neighbors," 2018 IEEE Int. Conf. Innov. Res. Dev., vol. 18, pp. 1-5, 2018.

[13] C. K. D. Wang et al., "Improving Defect Inspection Quality of Deep-Learning Network in Dense Beans by Using Hough Circle Transform for Coffee Industry," 2019 IEEE Int. Conf. Syst. Man Cybern., vol. 19, pp. 798-805, 2019.

[14] C. Pinto, J. Furukawa, H. Fukai, and S. Tamura, "Classification of Green Coffee Bean Images Based on Defect Types Using Convolutional Neural Network ( CNN )," 2017 Int. Conf. Adv. Informatics, Concepts, Theory, Appl., vol. 17, pp. 1-5, 2017.

[15] M. D. Podolsky, A. A. Barchuk, V. I. Kuznetcov, F. Natalia, V. S. Gaidukov, and S. A. Tarakanov, "Evaluation of Machine Learning Algorithm Utilization for Lung Cancer Classification Based on Gene Expression Levels," vol. 17, pp. 835-838, 2016.

[16] I. Cheng, G. M. Cortelazzo, A. Basu, and S. K. Tripathi, 3D Online Multimedia \& Games: Processing, Transmission and Visualization. Singapura: World Scientific, 2008.

[17] L. Velho, A. C. Frery, and J. Gomes, Image Processing for Computer Graphics and Vision. London: Springer, 2009.

[18] A. C. Bovik, Handboook of Image and Video Processing. London: Elsevier, 2010.

[19] B. Tso and P. M. Mather, Classification Methods for Remotely Sensed Data. London: Taylor \& Francis, 2001.

[20] B. Santoso, A. I. S. Azis, and Zohrahayaty, Machine Learning \& Reasoning Fuzzy Logic Algoritma, Manual, Matlab, \& Rapid Miner. Yogyakarta: Deepublish, 2020.

[21] E. Buulolo, Data Mining Untuk Perguruan Tinggi. Yogyakarta: Deepublish, 2020. 